\title{
CUCURBITS AS A MODEL SYSTEM FOR CROP POLLINATION MANAGEMENT
}

\author{
Jessica L. Knapp*1 and Juliet L. Osborne ${ }^{2}$ \\ ${ }^{1}$ Lund University, Department of Biology, Lund, Sweden \\ ${ }^{2}$ University of Exeter, Penryn Campus, Penryn, Cornwall, TRI0 9FE, UK
}

\begin{abstract}
Cucurbit crops have steadily increased in production over the last 50 years, particularly in Asia where pioneering technological advancements and genetic improvements have created new hybrid varieties. Generally, cucurbits are dependent on insect-pollination for fruit set and are popular species for pollination studies. This review systematically summarises pollination research conducted in the major food genera of cucurbits: Cucurbita, Cucumis, and Citrullus, to ask: I) what are cucurbits' requirement for pollination and their most effective pollinators? And 2) Does pollinator management increase pollinator visitation to, and yield of, cucurbit crops? These accounts of cucurbit pollination demonstrate that wild bee species such as Bombus terrestris, B. impatiens and Eucera spp. were frequently able to fulfil the pollination requirements of multiple cucurbit species. However, pollinator behaviour, pollen deposition on stigmas, and pollinators' contribution to yield vary between cucurbit species and study site. Nonetheless, the provision of additional floral resources at both field and farm scales may help to encourage pollination of cucurbit species whilst supporting pollinators' nutritional requirements beyond those already provided by the cucurbit crop. Synthesising studies on cucurbits' requirement for pollination and how pollinators vary spatially and temporally in the landscape can extend beyond cucurbit systems to inform growers and pollination ecologists of other pollinatordependent crop species wishing to maximise pollination services, species conservation; or both.
\end{abstract}

Keywords: Cucurbita, Cucumis, Citrullus, pollination, pollinator populations

\section{INTRODUCTION}

Cucurbits (Cucurbitaceae) are a large plant family which include major food crops within the Cucurbita (squash, pumpkin, courgette), Cucumis (cucumber, melon) and Citrullus (watermelon) genera (Kumar 2016). Over centuries, cucurbits have been domesticated for their fleshy fruits, roots, leaves, shoots, seeds, and flowers for food and commodity goods and thus are economically important crops (Bates et al. 1990; Bisognin 2002). Cultivated cucurbits are grown in a cultiar of agricultural environments from widespread monocultures to small-scale traditional garden systems and many species are able to persist in environmental conditions usually considered marginal for agriculture (Bates et al. 1990).

From a biological viewpoint, cucurbits' co-evolution with insects has inspired much scientific intrigue. For example, their ability to produce bitter cucurbitacins as a defence against insect herbivory has led to research into whether these compounds can be used for biological control, particularly against beetles (Metcalf et al. I982; Adler \& Hazzard 2009; Cavanagh et al. 2010). Likewise, cucurbits' dependency on pollination (Free 1993) means that cucurbit flowers offer large quantities of nectar and pollen as floral rewards to visiting insects, such as solitary bees, bumblebees and honeybees (Tepedino I98I; Vidal et al. 2006). In particular, the North American squash and gourd bees belonging to the

Received 23 February 2011, accepted 28 June 2011

*Corresponding author: jessica.knapp@biol.lu.se genera Eucera (Fig. 2A) and Xenoglossa are thought to rely exclusively on Cucurbita pollen to rear their offspring (Hurd, Linsley \& Michelbacher 1974; Tepedino 198I).

From an agricultural viewpoint, various mechanisms have been explored to improve cucurbit yield such as improving the sex expression of flowers (Rodriguez-Granados et al. 2017) and producing $F_{1}$ hybrid seed (Robinson 2000). Indeed, the yield (per hectare) of cucurbit crops has steadily increased over the last 50 years, particularly in Asia where pioneering technological advancements and genetic improvements, especially with seedless varieties not requiring pollination, have increased global production (Fig. I) (McCreight et al. 2013). Likewise, and most relevant to this review, cucurbit yield can also be increased by improving pollination (Hoehn et al. 2008; Kouonon et al. 2009).

Cucurbits are a popular plant family for pollination studies, particularly within the major food genera of Cucurbita (Hurd et al. 197I; Willis \& Kevan 1995; Artz et al. 20II; Petersen et al. 2014), Cucumis (Adamson et al. 2012; Ali et al. 2015; Motzke et al. 2015), and Citrullus (Kremen et al. 2004; Winfree et al. 2008; Pisanty et al. 20I5). This is likely because many cucurbit species are monoecious (Box I) with many ovules, so manipulating pollen deposition to examine its effect on yield is relatively straight forward. Because cucurbits are such a large and genetically diverse plant family, synthesising studies on their pollination can extend beyond these systems to inform pollination ecologists and growers of other pollinator-dependent species on how to maximise pollination services, species conservation; or both. 


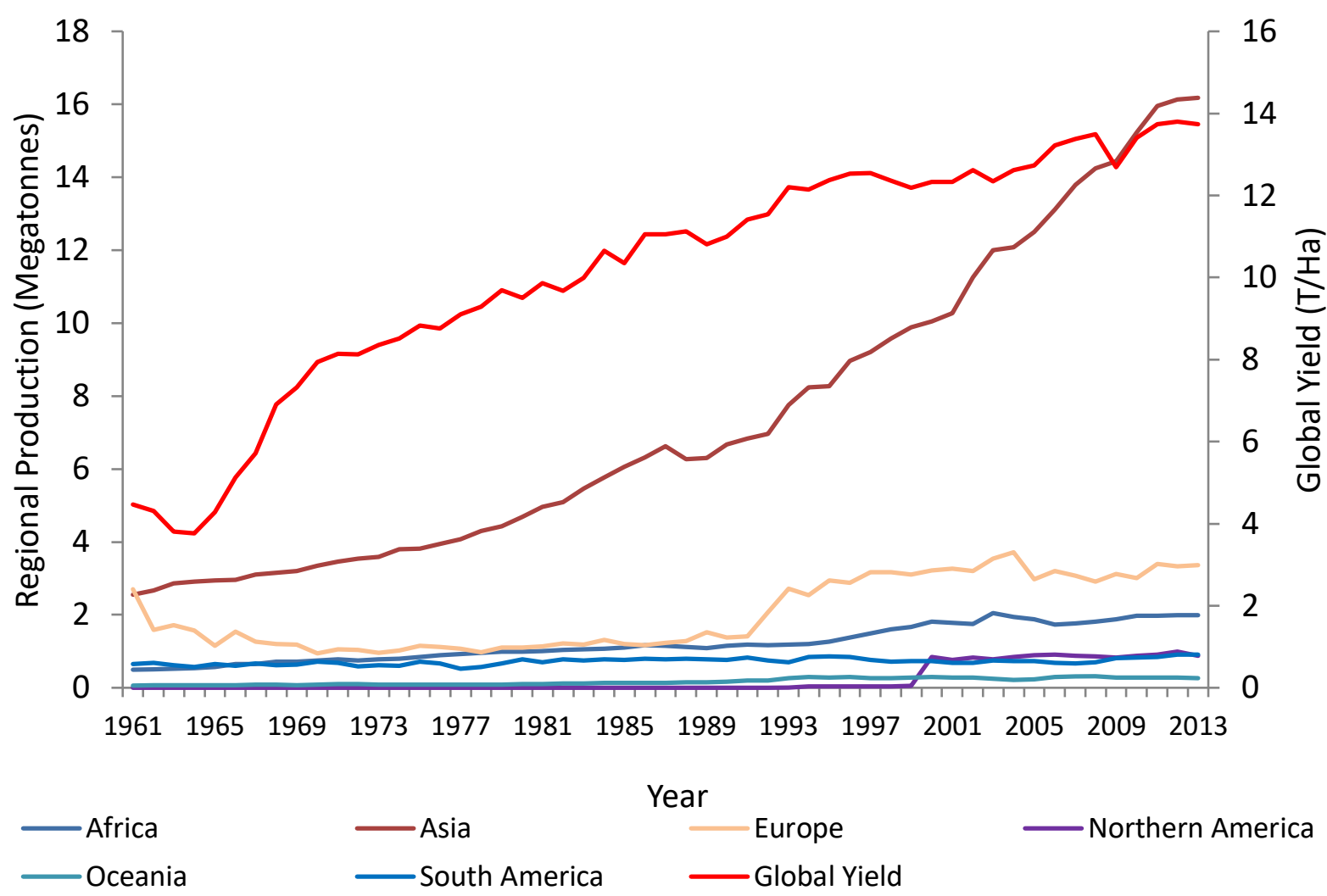

FIGURE I. Regional production (primary y axis) and average global yield (secondary y axis) of Cucurbita species from I96I to 2013. Data source: FAOSTAT (Aggregate, may include official, semi-official, estimated or calculated data).

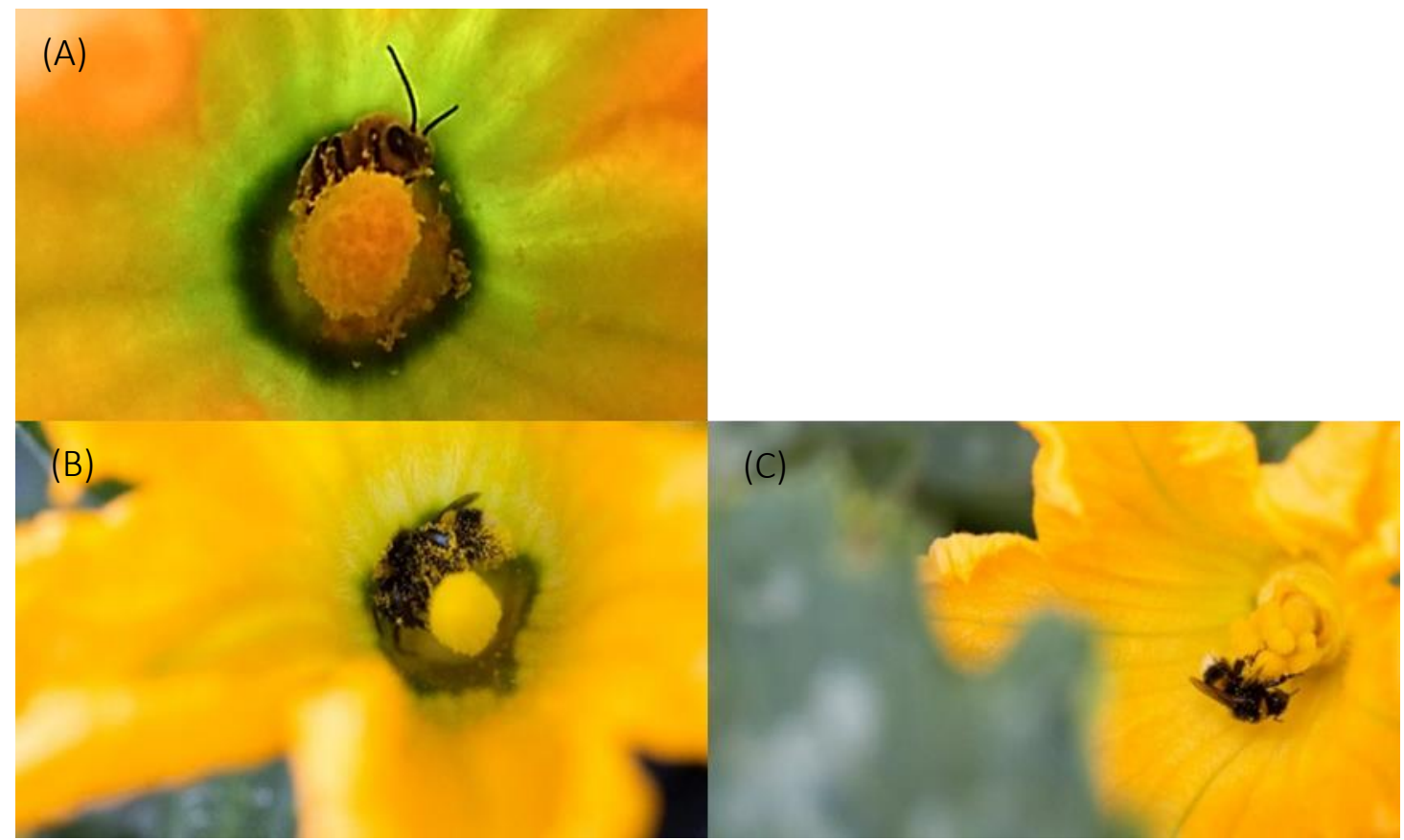

Figure 2(A) Eucera. pruinosa visiting a staminate courgette flower for pollen, (B) Bombus terrestris visiting a staminate courgette flower for nectar, and (C) B. terrestris visiting a pistillate Cucurbita pepo flower for nectar. Fig. 2A was taken in California, United States, and Figs. 2B and 2C were taken in the United Kingdom. Fig. 2B and 2C (C) Daphne Wong. 
This review aims to summarise pollination research conducted on the major food genera of cucurbits: Cucurbita, Cucumis, and Citrullus (Box I). Specifically, we ask: I) what are cucurbits' requirements for pollination and their most effective pollinators? And 2) Does pollinator management increase pollinator visitation or yield of cucurbit crops?

\section{MATERIALS AND METHODS}

We searched the ISI Web of Science, SCOPUS and Science Direct databases, and Google Scholar for studies that investigated pollination requirements, pollinator performance and pollination management in cucurbit crops. For all databases literature was searched between I 945 to September 2018 using the search terms: (Cucurbit ${ }^{*}$ ) OR (Cucumis) OR (Citrullus) OR (squash) OR (pumpkin) OR (courgette) OR (cucumber) OR ("melon), AND (Pollinat ${ }^{* *}$ ). Results are summarised in text and in Tables. I-4.

This review encompasses multiple ways in which pollination is directly or indirectly quantified (Box 2). Broadly, there are two approaches for quantifying pollination: the first directly estimates pollinator performance in terms of pollinator behaviour and / or pollen deposition on stigmas, whilst the second indirectly estimates pollinators' contribution to yield, usually measured as seed set or fruit weight (Ne'eman et al. 2010). Therefore, in this review pollinator visitation to crop flowers, abundance at crop flowers, and pollen deposition (whilst stigmas are receptive) are all considered to be measures of pollinator performance. On the other hand, seed set, fruit weight, fruit weight per plant, fruit number, and percentage fruit set are all considered measures of yield.

Measures of yield should be interpreted carefully since they depend on multiple resources such as water, nutrients, and pollen availability. But broadly, fruit number and percentage fruit set reflect the number of flowers pollinated, whilst seed set, and average fruit weight reflect the quantity of pollen that a flower receives (affecting the number of seeds per fruit or the fruit size). Arguably, when other environmental factors that influence fruit production e.g. soil type, resource availability and cultivation practices cannot be standardised, single visit pollen deposition is the most direct measure of pollination success (Kremen et al., 2004). It should also be

Box I. Scientific and common names of different cucurbit species included within this review. For each species the most common sex expressions, breeding systems, as well as average flower ratios and flower longevity are listed based on Bomfim et al. (2016). G, gynoecious, M, monoecious, A, andromonoecious, S, staminate; P, Pistillate.

\begin{tabular}{|c|c|c|c|c|c|c|}
\hline Scientific name & $\begin{array}{l}\text { Common } \\
\text { name(s) }\end{array}$ & Origin & Sex expression(s) & $\begin{array}{l}\text { Breeding } \\
\operatorname{system}(\mathrm{s})\end{array}$ & $\begin{array}{l}\text { Average } \\
\text { flower ratio } \\
(\mathrm{S}: \mathrm{P})\end{array}$ & $\begin{array}{l}\text { Average } \\
\text { anthesis }\end{array}$ \\
\hline Citrullus lanatus & Watermelon & $\begin{array}{l}\text { Tropical } \\
\text { Africa }\end{array}$ & $\begin{array}{l}\text { Monoecious is most } \\
\text { common but can also } \\
\text { be andromonoecious }\end{array}$ & $\begin{array}{l}\text { Self-pollination } \\
\text { and cross- } \\
\text { pollination }\end{array}$ & 5.I-I3:I & $\begin{array}{l}\approx 8 \text { hours } \\
\text { in field }\end{array}$ \\
\hline Cucumis melo & Melon & $\begin{array}{l}\text { Tropical } \\
\text { Africa }\end{array}$ & $\begin{array}{l}\text { Andromonoecious is } \\
\text { most common } \\
\text { (especially American } \\
\text { varieties), but can } \\
\text { also be monoecious } \\
\text { (especially European } \\
\text { varieties) }\end{array}$ & $\begin{array}{l}\text { Self-pollination } \\
\text { and cross- } \\
\text { pollination }\end{array}$ & $\mathrm{I} 2: \mathrm{I}$ & $\begin{array}{l}\approx \mathrm{I} 2 \text { hours } \\
\text { in field }\end{array}$ \\
\hline Cucumis sativus & Cucumber & India & $\begin{array}{l}\text { Monoecious is most } \\
\text { common but can also } \\
\text { be gynoecious, } \\
\text { hermaphroditic, or } \\
\text { andromonoecious. }\end{array}$ & $\begin{array}{l}\text { Self-pollination } \\
\text { and cross- } \\
\text { pollination }(\mathrm{M}) \text {, } \\
\text { or only cross- } \\
\text { pollination }(\mathrm{G}) \text {, } \\
\text { parthenocarpy. }\end{array}$ & $\begin{array}{l}\text { I0:I }(\mathrm{M}) \text {, or } \\
\text { all } \\
\text { predominantly } \\
\text { pistillate } \\
\text { flowers }(\mathrm{G})\end{array}$ & $\begin{array}{l}\approx 7 \text { hours } \\
\text { in field, } \approx 9 \\
\text { hours in } \\
\text { greenhouses }\end{array}$ \\
\hline $\begin{array}{l}\text { Cucurbita } \\
\text { maxima }\end{array}$ & $\begin{array}{l}\text { Buttercup } \\
\text { squash etc. }\end{array}$ & $\begin{array}{l}\text { South } \\
\text { America }\end{array}$ & Monoecious & $\begin{array}{l}\text { Self-pollination } \\
\text { and cross- } \\
\text { pollination }\end{array}$ & $3.5-10: 1$ & $\begin{array}{l}\approx 6 \text { hours } \\
\text { in field }\end{array}$ \\
\hline $\begin{array}{l}\text { Cucurbita } \\
\text { moschata }\end{array}$ & $\begin{array}{l}\text { Butternut } \\
\text { squash, } \\
\text { crookneck } \\
\text { pumpkin } \\
\text { etc. }\end{array}$ & $\begin{array}{l}\text { Central } \\
\text { America }\end{array}$ & Monoecious & $\begin{array}{l}\text { Self-pollination } \\
\text { and cross- } \\
\text { pollination }\end{array}$ & $3.5-10: 1$ & $\begin{array}{l}\approx 6 \text { hours } \\
\text { in field }\end{array}$ \\
\hline Cucurbita pepo & $\begin{array}{l}\text { Courgette, } \\
\text { zucchini, } \\
\text { summer } \\
\text { squash, } \\
\text { pumpkin }\end{array}$ & $\begin{array}{l}\text { Northern } \\
\text { Mexico/ } \\
\text { Southern } \\
\text { USA }\end{array}$ & Monoecious & $\begin{array}{l}\text { Self-pollination } \\
\text { and cross- } \\
\text { pollination }\end{array}$ & $3.5-10: 1$ & $\begin{array}{l}\approx 6 \text { hours } \\
\text { in field }\end{array}$ \\
\hline
\end{tabular}


Box 2. Measures of pollination included within this review.

\begin{tabular}{|ll|}
\hline Term & Definition \\
\hline Fruit number & Number of fruits, a measure of yield. \\
Pruit weight & Weight per fruit or for all fruits per plant, a measure of yield. \\
Pollen deposition & $\begin{array}{l}\text { Initial number of female flowers / Number of female flowers setting fruit X I00, a } \\
\text { measure of yield. }\end{array}$ \\
& $\begin{array}{l}\text { Number of pollen grains deposited on stigmas following visitation by individual bee } \\
\text { species or all bee species combined, for multiple visits. Single visit pollen deposition is } \\
\text { included in Appendix I. Pollen deposition is a measure of pollinator behaviour. }\end{array}$ \\
Pollinator performance & $\begin{array}{l}\text { A relative measure of pollinator effectiveness, based on pollinator behaviour (visitation } \\
\text { (rate and/or timing), single visit pollen deposition) or contribution to yield (fruit } \\
\text { weight, fruit number, seed set). } \\
\text { Number of seeds per fruit, a measure of yield. } \\
\text { Visitation }\end{array}$ \\
\hline
\end{tabular}

noted, in cucurbits that the actual timing of pollination can affect the final number of fruits: Cucurbit flowers open early in the morning, when both stigma receptivity and pollen viability are at their greatest (Bomfim et al. 2016) and diurnal pollen transfer is likely to be important in cucurbits since stigma receptivity rapidly declines within a day (Bomfim et al. 2016). Thus, flowers on which pollen is deposited early in the day are more likely to set fruit. Also, the presence of already pollinated fruits has been shown to significantly decrease the number of pistillate flowers and increase the likelihood of new fruit aborting in Cucurbita pepo (Stephenson et al. 1988).

\section{RESULTS AND DISCUSSION}

\section{Pollinator dependency}

Cucurbits have been described as having an 'essential need' for insect-mediated pollination (Free 1993; Klein et al. 2007) and research has shown that seed number (Roldán-Serrano \& Guerra-Sanz 2005) and fruit set of Cucurbita pepo (RoldánSerrano \& Guerra-Sanz 2005; Vidal et al. 20I0) and Cucumis sativus (Gingras, Gingras \& DeOliveira I999; Walters 2005) are positively correlated with the number of pollinator visits that each flower receives. Similarly, fruit has been shown to abort in the absence of pollination in Cucumis sativus (Motzke et al. 2015), Cucumis melo (Kouonon et al. 2009), Cucurbita moschata (Hoehn et al. 2008), and Cucurbita pepo (Martínez et al. 20I4). Interestingly, the addition of honey bee colonies did not increase the yield of smaller-sized Cucurbita pepo varieties as much as larger ones; suggesting that alternative pollinator species may be more important in these varieties or that some smaller varieties may be able to set fruit with a smaller pollen load (Walters \& Taylor 2006).

However, several varieties of Cucurbita pepo have been observed to set fruit in the absence of fertilisation, and therefore pollination, via parthenocarpy (Robinson \& Reiners 1999; Kurtar 2003; Martínez et al. 2013; Knapp \& Osborne
2017). This genetic trait is desirable for growers in crops that are usually pollinator-dependent because fruit is able to form is conditions that are adverse for pollinators, potentially extending geographic and climatic ranges of production (Knapp et al. 2016). Seedlessness in fruits, caused by the lack of fertilisation, can be an important measure of quality, for example in green-house grown Cucumis sativus, where seedlessness is generally appreciated by consumers (Knapp et al. 2016). However, evidence suggests that parthenocarpic varieties may still produce a greater quantity and quality of fruits, including a higher sugar content (Shin et al. 2007), when they are pollinated by insects (Martínez et al. 2013; Robinson \& Reiners 1999; Nicodemo et al. 2013).

Whilst there have been extensive selective breeding programmes, use of growth hormones and even genetic modifications for parthenocarpy (Knapp et al. 2016), this review focuses on pollination of pollinator-dependent varieties. Nonetheless, evidence of parthenocarpy in cucurbit crops suggests that, to get a more complete picture of pollinator dependence in crops, varietal information is required - both in terms of pollinator dependence, but also in terms of choices that farmers are making (Klein et al. 2007; Melathopoulos et al. 2015). Realistically, the best way of obtaining this information is if the pollination requirements of each variety are tested by organisations or institutes conducting variety trials and that this information is made freely available alongside other trait details.

\section{Relative importance of pollination to yield}

Whilst pollination affects cucurbit yield, there are many other environmental factors which contribute and interact with each other to influence fruit set, such as nutrient and water availability, herbivore damage and weed competition (Tab. I). If any of these factors are deficient then yield may decrease, widening the yield gap between actual and attainable yields (Bommarco et al. 20I3). For example, Motzke et al (2015) showed that weed control and fertilisation were able 
TABLE I. Environmental factors affecting cucurbit yield. Effects were classed as 'positive', 'negative' or 'none' based on the direction of the relationship and statistical significance $(P<0.05)$ presented in the original studies.

\begin{tabular}{|c|c|c|c|c|}
\hline Species & $\begin{array}{l}\text { Sex expression, } \\
\text { breeding system }\end{array}$ & $\begin{array}{l}\text { Study } \\
\text { location }\end{array}$ & Key findings & Citation \\
\hline $\begin{array}{l}\text { Cucumis } \\
\text { sativus }\end{array}$ & $\begin{array}{l}\text { Monoecious variety, } \\
\text { some parthenocarpy } \\
\text { observed in no } \\
\text { pollination controls }\end{array}$ & $\begin{array}{l}\text { Field } \\
\text { study, } \\
\text { Indonesia }\end{array}$ & $\begin{array}{l}\text { When tested independently, pollination, weed control, and } \\
\text { fertilisation had a positive effect on fruit weight, however, } \\
\text { herbivore control had no effect on fruit weight. } \\
\text { When tested in combination, pollination and weed control had a } \\
\text { positive effect on fruit weight. } \\
\text { 'Pollination' compared open pollination to no pollination. }\end{array}$ & $\begin{array}{l}\text { (Motzke } \\
\text { et al. } \\
\text { 20I5) }\end{array}$ \\
\hline $\begin{array}{l}\text { Cucumis } \\
\text { sativus }\end{array}$ & $\begin{array}{l}\text { Monoecious variety, } \\
\text { assumed to be } \\
\text { dependent on insect } \\
\text { pollination. }\end{array}$ & $\begin{array}{l}\text { Field } \\
\text { study, } \\
\text { USA }\end{array}$ & $\begin{array}{l}\text { When tested independently, root herbivory had a negative effect } \\
\text { on fruit weight, whilst leaf herbivory and pollination had no } \\
\text { effect on fruit weight. } \\
\text { When tested in combination, pollination and root herbivory, } \\
\text { pollination and leaf herbivory, and pollination, root herbivory } \\
\text { and leaf herbivory had no effect on fruit weight. } \\
\text { When tested independently, root herbivory had a negative effect } \\
\text { on seed set, leaf herbivory had positive effect on seed set and } \\
\text { pollination had no effect on seed set. } \\
\text { When tested in combination, pollination and root herbivory had } \\
\text { a positive effect on seed set (pollination mitigated root } \\
\text { herbivory), whilst pollination and leaf herbivory, and pollination, } \\
\text { root herbivory and leaf herbivory had no effect on seed set. } \\
\text { 'Pollination' compared hand pollination to open pollination. }\end{array}$ & $\begin{array}{l}\text { (Barber et } \\
\text { al. 20II) }\end{array}$ \\
\hline $\begin{array}{l}\text { Cucurbita } \\
\text { moschata }\end{array}$ & $\begin{array}{l}\text { Monoecious variety, } \\
\text { assumed to be } \\
\text { dependent on insect } \\
\text { pollination. }\end{array}$ & $\begin{array}{l}\text { Field } \\
\text { study, } \\
\text { USA }\end{array}$ & $\begin{array}{l}\text { When tested independently, pollination and root herbivory had a } \\
\text { positive effect on fruit weight, however, leaf herbivory had no } \\
\text { effect on fruit weight. } \\
\text { When tested in combination, pollination and root herbivory and } \\
\text { pollination and leaf herbivory had no effect on fruit weight. } \\
\text { Pollination, root herbivory and leaf herbivory, and their } \\
\text { interactions had no effect on seed set. } \\
\text { 'Pollination' compared hand pollination to open pollination. }\end{array}$ & $\begin{array}{l}\text { (Hladun } \\
\text { \& Adler } \\
2009 \text { ) }\end{array}$ \\
\hline
\end{tabular}

to reduce the yield gap of Cucumis sativus by $45 \%$ and $18 \%$ respectively; however, these factors, even in combination, were unable to compensate for a total absence of pollination which increased the yield gap by $75 \%$ (the difference between open and non-pollinated flowers) (Tab. I). In contrast, root herbivory had a negative effect on Cucumis sativus yield despite crop flowers receiving high levels of pollination, demonstrating that below-ground herbivores may have profound effects on plant performance (Barber et al. 20II) (Tab. I). Soil nitrogen has also been shown to increase the number, weight and viability of pollen grains with flowers hand pollinated from pollen grown in higher nitrogen environments observed to produce Cucurbita pepo fruits with more seeds compared to hand pollinated flowers using pollen from lower nitrogen environments (Lau Tak-Cheung \& Stephenson 1993).

Relatively few studies in cucurbits (Tab. I) have examined how a plant's health interacts with the level of pollination it has received to influence fruit set. Drought stress, nutrient deficiencies and diseases such as cucumber mosaic virus and powdery mildew are relatively common in cucurbit production, often more so than direct pest damage (Agriculture and Horticulture Developement Board 2013). Since biological control may reduce aphid populations, which are common vectors of cucumber mosaic virus, and fungicides can reduce powdery mildew, fully-factorial experiments could be established to test the effect of disease control (biological and/or chemical) in relation to different levels of pollination (i.e. hand, open and no pollination), nutrient (e.g. fertiliser use), and water availability (e.g. irrigation and/or rain covers) on fruit set. Results from this type of experiment would help growers to realise the importance of pollination relative to other factors such as disease. A more complete understanding of the environmental factors affecting fruit set is vital to ensure that ecologists do not promote the conservation of one ecosystem service at the expense of another and that growers are able to prioritise key limiting services in their management for optimal crop yields.

\section{Pollinator performance}

Cucurbits are pollinated by multiple species of honeybees, bumblebees, and solitary bees (Tab. 2). Consequently, several studies have compared pollinator performance in cucurbit crops by exploring aspects of pollinator behaviour (visitation rate and diurnal activity patterns, single visit pollen deposition) and/ or their contribution to yield (fruit weight, fruit number, seed number) (Tab. 2). 
TABLE 2. Key findings from studies looking at measures of pollinator performance such as, pollinator visitation to, and abundance at crop flowers, as well as pollen deposition in various cucurbit crops.

\begin{tabular}{|c|c|c|c|c|}
\hline Species & Sex expression, breeding system & Key findings & $\begin{array}{l}\text { Study } \\
\text { location }\end{array}$ & Citation \\
\hline Citrullus lanatus & $\begin{array}{l}\text { Monoecious variety, no fruit set } \\
\text { in no pollination controls. }\end{array}$ & $\begin{array}{l}\text { Lasioglossum spp. were more effective } \\
\text { than } A \text {. mellifera at increasing seed set. }\end{array}$ & $\begin{array}{l}\text { Field study, } \\
\text { Greece }\end{array}$ & $\begin{array}{l}\text { (Garantonakis et al. } \\
\text { 2016) }\end{array}$ \\
\hline Citrullus lanatus & $\begin{array}{l}\text { Monoecious variety, assumed to } \\
\text { be dependent on insect } \\
\text { pollination. }\end{array}$ & $\begin{array}{l}\text { Nomia oxybeloides was more effective } \\
\text { than A. florea at single-visit pollen } \\
\text { deposition (no Bombus spp. present) }\end{array}$ & $\begin{array}{l}\text { Field study, } \\
\text { Pakistan }\end{array}$ & (Ali et al. 2015) \\
\hline Citrullus lanatus & $\begin{array}{l}\text { Monoecious variety with some } \\
\text { perfect flowers, some fruit set } \\
\text { in no insect pollination controls } \\
\text { hypothesised to be from stray } \\
\text { insects. }\end{array}$ & $\begin{array}{l}\text { Bombus impatiens was more effective } \\
\text { than } A \text {. mellifera at single-visit pollen } \\
\text { deposition. }\end{array}$ & $\begin{array}{l}\text { Field study, } \\
\text { USA }\end{array}$ & $\begin{array}{l}\text { (Campbell et al. } \\
\text { 2018) }\end{array}$ \\
\hline Citrullus lanatus & $\begin{array}{l}\text { Monoecious variety, assumed to } \\
\text { be dependent on insect } \\
\text { pollination. }\end{array}$ & $\begin{array}{l}\text { Lassioglossum spp. was more effective } \\
\text { than A. mellifera at single-visit pollen } \\
\text { deposition and visited earlier in the day } \\
\text { (no Bombus spp. present) }\end{array}$ & $\begin{array}{l}\text { Field study, } \\
\text { Kenya }\end{array}$ & $\begin{array}{l}\text { (Njoroge et al. } \\
2010)\end{array}$ \\
\hline $\begin{array}{l}\text { Citrullus lanatus } \\
\text { and Cucumis } \\
\text { sativus }\end{array}$ & $\begin{array}{l}\text { Gynoecious and monoecious } \\
\text { varieties, some parthenocarpy } \\
\text { observed in no pollination } \\
\text { controls but all aborted within } \\
\text { I week. }\end{array}$ & $\begin{array}{l}\text { Bombus spp. were more effective than } \\
\text { A. mellifera for increasing seed set }\end{array}$ & $\begin{array}{l}\text { Field study, } \\
\text { USA }\end{array}$ & $\begin{array}{l}\text { (Stanghellini et al. } \\
\text { I998) }\end{array}$ \\
\hline Cucumis melo & $\begin{array}{l}\text { Monoecious variety, assumed to } \\
\text { be dependent on insect } \\
\text { pollination. }\end{array}$ & $\begin{array}{l}\text { Lasioglossum spp. was more effective } \\
\text { than A. florea at single visit pollen } \\
\text { deposition (no Bombus spp. present) }\end{array}$ & $\begin{array}{l}\text { Field study, } \\
\text { Pakistan }\end{array}$ & (Ali et al. 2015) \\
\hline Cucumis melo & $\begin{array}{l}\text { Andromonoecious variety, } \\
\text { however, perfect flowers } \\
\text { assumed to be dependent on } \\
\text { pollination. }\end{array}$ & $\begin{array}{l}\text { No difference between } A \text {. mellifera and } \\
\text { B. impatiens at single-visit pollen } \\
\text { deposition, however, } A \text {. mellifera had a } \\
\text { lower pollen removal to pollen } \\
\text { deposition ratio, suggesting it is a more } \\
\text { effective pollinator. }\end{array}$ & $\begin{array}{l}\text { Field study, } \\
\text { USA }\end{array}$ & $\begin{array}{l}\text { (Goodell \& } \\
\text { Thomson 2007) }\end{array}$ \\
\hline Cucurbita maxima & $\begin{array}{l}\text { Monoecious variety, assumed to } \\
\text { be dependent on insect } \\
\text { pollination. }\end{array}$ & $\begin{array}{l}\text { Bombus spp. were more effective than } \\
\text { A. mellifera at pollen deposition, } \\
\text { however, A. mellifera had a higher } \\
\text { visitation frequency than Bombus spp. }\end{array}$ & $\begin{array}{l}\text { Field study, } \\
\text { Germany }\end{array}$ & (Pfister et al. 2018) \\
\hline $\begin{array}{l}\text { Cucurbita } \\
\text { moschata }\end{array}$ & $\begin{array}{l}\text { Monoecious variety, no fruit set } \\
\text { in no pollination controls. }\end{array}$ & $\begin{array}{l}\text { High species richness of pollinators } \\
\text { increased seed set. }\end{array}$ & $\begin{array}{l}\text { Field study, } \\
\text { Indonesia }\end{array}$ & (Hoehn et al. 2008) \\
\hline $\begin{array}{l}\text { Cucurbita } \\
\text { moschata }\end{array}$ & $\begin{array}{l}\text { Monoecious variety, assumed to } \\
\text { be dependent on insect } \\
\text { pollination. }\end{array}$ & $\begin{array}{l}\text { Eucera limitaris was more abundant and } \\
\text { more effective than } A \text {. mellifera at } \\
\text { single-visit pollen deposition (no } \\
\text { Bombus spp. present) }\end{array}$ & $\begin{array}{l}\text { Field study, } \\
\text { Mexico }\end{array}$ & $\begin{array}{l}\text { (Canto-Aguilar \& } \\
\text { Veterinaria 2000) }\end{array}$ \\
\hline Cucurbita pepo & $\begin{array}{l}\text { Monoecious variety, assumed to } \\
\text { be dependent on insect } \\
\text { pollination. }\end{array}$ & $\begin{array}{l}\text { Bombus impatiens was more effective } \\
\text { than } A \text {. mellifera and Eucera pruinosa at } \\
\text { single-visit pollen deposition, however, } \\
\text { A. mellifera was a more abundant } \\
\text { pollinator than } B \text {. impatiens and } P \text {. } \\
\text { pruinosa. }\end{array}$ & $\begin{array}{l}\text { Field study, } \\
\text { USA }\end{array}$ & $\begin{array}{l}\text { (Artz \& Nault } \\
201 \mathrm{I})\end{array}$ \\
\hline Cucurbita pepo & $\begin{array}{l}\text { Monoecious variety, assumed to } \\
\text { be dependent on insect } \\
\text { pollination. }\end{array}$ & $\begin{array}{l}\text { A. dorsata was the most abundant } \\
\text { pollinator, however, Nomia spp. were } \\
\text { more effective than } A \text {. dorsata at single- } \\
\text { visit pollen deposition and fruit set (no } \\
\text { Bombus spp present) }\end{array}$ & $\begin{array}{l}\text { Field study, } \\
\text { Pakistan }\end{array}$ & (Ali et al. 20I4) \\
\hline Cucurbita pepo & $\begin{array}{l}\text { Monoecious variety, assumed to } \\
\text { be dependent on insect } \\
\text { pollination. }\end{array}$ & $\begin{array}{l}\text { Bombus spp. were more effective than } \\
\text { A. cerana at single-visit pollen } \\
\text { deposition, however, A. cerana was a } \\
\text { more abundant pollinator than Bombus } \\
\text { spp. }\end{array}$ & $\begin{array}{l}\text { Field study, } \\
\text { China }\end{array}$ & (Xie \& An 20I4) \\
\hline
\end{tabular}


When present, Bombus spp. are frequently observed to be the most effective pollinators of cucurbit crops, despite Apis spp. often being more abundant at crop flowers (Tab. 2). For example, Artz and Nault (20II) observed Bombus impatiens C., depositing more than three times the number of pollen grains per stigma and nearly always contacting the stigma compared to A. mellifera and Eucera pruinosa S, in Cucurbita pepo. On the other hand, Eucera limitaris was more abundant and more effective than $A$. mellifera at single-visit pollen deposition (no Bombus spp. present) in Cucurbita moschata (Canto-aguilar \& Veterinaria 2000). Indeed, P. pruinosa has been shown to forage for Cucurbita pollen (Willis \& Kevan 1995) and Lassioglossum spp. forage for Citrullus pollen (Njoroge et al. 2010) early in the morning and thus have a higher pollination potential. However, these foraging visits will only contribute to pollination if pistillate flowers are also visited. Outside of intensive production systems in North America and Europe, more diverse assemblages of pollinators have been observed to fulfil the pollination requirements of Cucumis melo, Citrullus lanatus (Ali et al. 2015), Cucurbita pepo (Ali et al. 2014) and Cucurbita moschata (Hoehn et al. 2008) (Tab. 2). Likewise, Pisanty et al. (20I5) observed spatial and temporal variation in pollinator species' visitation to Citrullus lanatus, suggesting niche complementarity.

Since the majority of cucurbit species are monoecious (Box I), consideration must also be given to whether some pollinator species show a preference for either staminate or pistillate flowers which could significantly influence pollen transfer. Indeed, bee species have been shown to preferentially choose and forage for longer in staminate flowers as their nectar has a higher sugar content (Knapp et al. 2018) and the nectaries are harder to access than pistillate flowers (Tepedino I98I; Artz \& Nault 20II; Phillips \& Gardiner 20I5). In the United Kingdom, Bombus terrestris L. has been shown to have a more equal preference for staminate (Fig. 2B) and pistillate Cucurbita pepo flowers (Fig. 2C) and carried more loose pollen grains than $A$. mellifera, thought to be desirable for optimum pollen transfer and therefore, fruit set (Knapp et al. 2018). This study and others from outside North America (Tab.2 and Tab. 4) have also shown that maximal Cucurbita yields can be achieved without Eucera and Xenoglossa species, North American bee species which are frequently cited as the most effective pollinators of Cucurbita crops (Hurd et al. 1974; Tepedino 198I).

\section{Supplementing fields with managed pollinators}

To mitigate potential fluctuations in wild bee abundance some cucurbit producers choose to supplement fields with managed bee species (Mader et al. 2010). Despite managed bee species being present in fields, visitation rates to crop flowers can be variable and benefits to crop yields sometimes not seen (Tab. 3). This could be because of a high abundance of wild pollinators and therefore little difference in pollination between control sites and those where managed pollinators have been added (Artz et al. 20I I; Petersen et al. 2013, 20I4, $\mathrm{Tab} 3$.). This suggests that in many cases pollination services by wild bees may be sufficient for optimal yields (Pfister et al. 2018). Therefore, before supplementing fields with managed pollinators, it would be advantageous to determine if a site is experiencing a pollination deficit. This can be done by comparing yields from open and hand pollinated flowers (Petersen et al. 20I4) or by combining pollinator visitation (Julier \& Roulston 2009) or pollen deposition data at sites (Xie \& An 2014; Pfister et al. 2018) with published data on the pollination requirements of the crop ( $\mathrm{Tab} .3$ ). If farmers could use similar techniques (Fig. 3) then they could potentially reduce the amount that they spend on hiring in temporary pollination services.

\section{Management for wild pollinators}

Cucurbit yield can also increase if a crop is surrounded by more diverse habitats where increased species richness and abundance of wild pollinators can improve pollination services (Hoehn et al. 2008; Garibaldi et al. 20II) and provide insurance against any pollinator loss (Shuler et al 2005). Improving the quantity and quality of pollen and nectar resources available for pollinators, and allowing areas to remain undisturbed for the insects to nest, mate, and hibernate could benefit pollinator populations and therefore reduce pollination deficits (Bommarco et al. 2013). This can be done at a field scale by providing additional areas for food and nesting and following principles of integrated pest management, as well as at a landscape scale by promoting larger areas of natural habitat (Tab. 4). However, the effectiveness of field scale pollinator-supporting practices are often variable (Tab. 4), with more simplistic landscapes generally showing greater benefits after interventions than complex landscapes (Batáry, Báldi, Kleijn, \& Tscharntke, 20II; Scheper et al., 20I3, Tab. 4).

Wild flowers co-flowering with crops have been shown to increase solitary bee abundance in Cucumis melo and Citrullus lanatus (Winfree et al. 2008) as well as Bombus abundance in Cucurbita pepo (Knapp et al. 2018) (Tab. 4). Naturallyoccurring wild flowers such as agricultural weeds and hedgerow flowers are frequently overlooked floral resources for pollinators (Bretagnolle \& Gaba 2015) despite being free and sustainable, and thus easily available to growers. These wild flowers are unlikely to be competing with cucurbit flowers for pollination services as both $B$. terrestris and $A$. mellifera have been observed to visit crop flowers more often than wild flowers in the morning when Cucurbita pepo flowers were open, before 'switching' to wild flowers after $C$. pepo senescence (Knapp et al. 2018). These findings provide the first evidence of bee fidelity (from non-specialists) to a Cucurbita crop.

Tillage has been shown to have variable results on bee abundance and visitation ( $\mathrm{Tab} 4$.), despite $P$. pruinosa preferentially laying their eggs in crop areas at depths around I2 to $30 \mathrm{~cm}$ (Julier \& Roulston 2009; Hurd et al. 1974). For example, no-tillage farms have been shown to have an almost three-fold increase in $P$. pruinosa density (Shuler et al. 2005), whilst other studies have observed no effect of tillage on $P$. pruinosa abundance (Julier \& Roulston 2009, Minter \& Bessin 20I4). This may be a result of survey timings, as Julier \& Roulston (2009) surveyed in mid-August, compared to Shuler et al. (2005) who surveyed in July when P. pruinosa is thought to emerge (Mathewson 1968). Given P. pruinosa requirement for cucurbit pollen, allowing areas to remain undisturbed for nesting and hibernation near to the crop may be particularly important (Mathewson I968). 
TABLE 3. Effect of supplemented commercial pollinators on cucurbit pollination. Effects are classified as 'positive', 'negative' or 'none' based on the direction of the relationship and statistical significance $(\mathrm{P}<0.05)$ presented in the original studies.

\begin{tabular}{|c|c|c|c|c|c|}
\hline Species & $\begin{array}{l}\text { Sex expression, } \\
\text { breeding system }\end{array}$ & $\begin{array}{l}\text { Study } \\
\text { location }\end{array}$ & Level of pollination & Key findings & Citation \\
\hline $\begin{array}{l}\text { Cucumis } \\
\text { sativus, } \\
\text { Cucumis } \\
\text { melo, and } \\
\text { Cucurbita } \\
\text { (spp) }\end{array}$ & $\begin{array}{l}\text { Several varieties } \\
\text { assumed to be } \\
\text { dependent on } \\
\text { pollination. } C \text {. } \\
\text { sativus described as } \\
\text { self-fertile but } \\
\text { benefitting from } \\
\text { pollination }\end{array}$ & $\begin{array}{l}\text { Field study, } \\
\text { USA }\end{array}$ & $\begin{array}{l}\text { Pollination not limiting- } \\
\text { visitation rate from wild } \\
\text { bees } 83 \%\end{array}$ & $\begin{array}{l}\text { A. mellifera had no effect } \\
\text { on A. mellifera visitation to } \\
\text { crop flowers. }\end{array}$ & $\begin{array}{l}\text { (Adamson } \\
\text { et al. 2012) }\end{array}$ \\
\hline $\begin{array}{l}\text { Cucurbita } \\
\text { peop, } C . \\
\text { moschata, } \\
\text { and } C . \\
\text { maxima }\end{array}$ & $\begin{array}{l}\text { Monoecious variety } \\
\text { assumed to be } \\
\text { dependent on } \\
\text { pollination. }\end{array}$ & $\begin{array}{l}\text { Field study, } \\
\text { USA }\end{array}$ & $\begin{array}{l}\text { Pollination likely limiting } \\
\text { yield - } 6 \text { visits per hour } \\
\text { in } A . \text { mellifera } \\
\text { supplementation treatment } \\
\text { compared to } \sim 4 \text { visits per } \\
\text { hour in no supplementation } \\
\text { treatment. }\end{array}$ & $\begin{array}{l}\text { A. mellifera had a positive } \\
\text { effect on fruit weight but } \\
\text { no effect on the number of } \\
\text { fruits per hectare. }\end{array}$ & $\begin{array}{l}\text { (Walters \& } \\
\text { Taylor } \\
\text { 2006) }\end{array}$ \\
\hline $\begin{array}{l}\text { Cucurbita } \\
\text { pepo }\end{array}$ & $\begin{array}{l}\text { Monoecious variety, } \\
\text { no fruit set in no } \\
\text { pollination controls. }\end{array}$ & $\begin{array}{l}\text { Field study, } \\
\text { USA }\end{array}$ & $\begin{array}{l}\text { Pollination deficit not } \\
\text { quantified. } \\
\text { B. impatiens shown to be } \\
\text { the most effective pollinator } \\
\text { in the system. }\end{array}$ & $\begin{array}{l}\text { B. impatiens had a positive } \\
\text { effect on the number of } \\
\text { fruits per plants but not } \\
\text { fruit weight. }\end{array}$ & $\begin{array}{l}\text { (Artz \& } \\
\text { Nault } \\
20 I I)\end{array}$ \\
\hline $\begin{array}{l}\text { Cucurbita } \\
\text { pepo }\end{array}$ & $\begin{array}{l}\text { Monoecious variety } \\
\text { assumed to be } \\
\text { dependent on } \\
\text { pollination. }\end{array}$ & $\begin{array}{l}\text { Field study, } \\
\text { USA }\end{array}$ & $\begin{array}{l}\text { Pollination likely limiting } \\
\text { yield -visitation rate from } \\
\text { wild bees } 59 \% \text {. }\end{array}$ & $\begin{array}{l}\text { A. mellifera had a positive } \\
\text { effect on } A \text {. mellifera } \\
\text { visitation to crop flowers. } \\
\text { A. mellifera had no effect } \\
\text { on } B \text {. impatiens visitation to } \\
\text { crop flowers. } \\
\text { A. mellifera had a negative } \\
\text { effect on } P \text {. pruinosa } \\
\text { visitation to crop flowers. } \\
\text { Field size had no effect on } \\
B . \text { impatiens, } A \text {. mellifera, } \\
\text { and P. pruinosa abundance. }\end{array}$ & $\begin{array}{l}\text { (Artz et al. } \\
201 \mathrm{I})\end{array}$ \\
\hline $\begin{array}{l}\text { Cucurbita } \\
\text { pepo }\end{array}$ & $\begin{array}{l}\text { Monoecious variety } \\
\text { assumed to be } \\
\text { dependent on } \\
\text { pollination. }\end{array}$ & $\begin{array}{l}\text { Field study, } \\
\text { USA }\end{array}$ & $\begin{array}{l}\text { Pollination deficit not } \\
\text { quantified. }\end{array}$ & $\begin{array}{l}\text { A. mellifera had no effect } \\
\text { on A. mellifera visitation to } \\
\text { crop flowers and fruit } \\
\text { weight. } \\
\text { B. impatiens had no effect } \\
\text { B. impatiens visitation to } \\
\text { crop flowers and fruit } \\
\text { weight. }\end{array}$ & $\begin{array}{l}\text { (Petersen et } \\
\text { al. 2013) }\end{array}$ \\
\hline $\begin{array}{l}\text { Cucurbita } \\
\text { pepo }\end{array}$ & $\begin{array}{l}\text { Monoecious variety } \\
\text { assumed to be } \\
\text { dependent on } \\
\text { pollination. }\end{array}$ & $\begin{array}{l}\text { Field study, } \\
\text { USA }\end{array}$ & $\begin{array}{l}\text { Pollination not limiting to } \\
\text { yield- no difference in yield } \\
\text { between hand- and open- } \\
\text { pollinated flowers. }\end{array}$ & $\begin{array}{l}\text { B. impatiens had no effect } \\
\text { on } B \text {. impatiens visitation, } \\
\text { fruit weight, and seed set. }\end{array}$ & $\begin{array}{l}\text { (Petersen et } \\
\text { al. 20I4) }\end{array}$ \\
\hline
\end{tabular}

Interestingly, in the studies we found, pesticide /insecticide use had no effect on bee visitation (Shuler et al. 2005; Motzke et al. 2015), pollen deposition (Kremen et al. 2004), or yield (Motzke et al. 2015) (Tab. 4). Whilst trap crops may not directly increase yields of focal cash crops (Tab. $4)$, they have proven successful at reducing the abundance of pests. For example, Adler \& Hazzard (2009) observed significantly fewer striped cucumber beetles (Acalymma vittatum) in Cucurbita moschata, the focal cash crop, with multiple cucurbit species as trap crops. Following a similar experimental design, Cavanagh et al. (2010) showed that trap crops could reduce insecticide use by $97 \%$ compared to control fields. Importantly, both studies found no effect of trap crops on pollinator visitation to Cucurbita moschata, 
suggesting no competition between trap crops and focal crops for pollination services (Adler \& Hazzard 2009; Cavanagh et al. 20I0, Tab. 4).

At a landscape scale, pollination services to cucurbit crops by wild bees have been shown to relate to the amount of natural habitat surrounding a site (Tab. 4). For example, Kremen et al. (2004) found that pollination by native bees in Citrullus lanatus were strongly associated with the proportion of natural habitat within a I to $2.5 \mathrm{~km}$ radius of farm sites, meaning that based on the area of natural habitat, pollination services to a given site could be estimated (Kremen et al. 2004). The effect of natural habitat was also more important than organic versus conventional farming for predicting pollen deposition and pollinator abundance in Citrullus lanatus (Kremen et al. 2004, Tab. 4). As many agricultural systems are isolated from natural habitats, crop producers may need to provide floral resources and nesting sites suitable for pollinators. In the UK, farm stewardship schemes provide guidance on hedgerow and field margin management, particularly favoured by bumblebee species (Osborne et al. 2008; Carvell et al. 2015; Dicks et al. 2015; Wood et al. 2015). Costs can also be directly offset by increased profit from improved quality and quantity of yields. For example, considering an example of a non-cucurbit crop: the economic benefit of improved Vaccinium corymbosum L. yields following wild flower establishment has been shown to exceed the original cost of implementation (Blaauw \& Isaacs 20I4).

Large areas of mass-flowering crops, including the cucurbit crop itself, may dilute pollinator densities or, if the area is small, concentrate pollinator densities (Holzschuh et al. 2016). This will be especially pronounced if additional food and nesting sites are not provided, meaning that pollinators move transiently between available forage rather than increasing their population size (Holzschuh et al. 2016). In a UK study of Cucurbita pepo, whilst B. terrestris showed a strong fidelity to the crop flowers' bountiful nectar, no foragers were found returning to their colonies with $C$. pepo pollen loads (Knapp et al. 2018). Despite C. pepo pollen being relatively high in protein (Petersen et al. 2013), its large sticky grains may make it difficult for the bees to collect (Vaissière \& Vinson 1994). Indeed, B. terrestris has been observed to remove excess pollen grains from their bodies early in the morning (Personal observations). Whilst $B$. terrestris has been observed to collect Cucurbita pollen in flight cages (Vaissière \& Vinson 1994), no studies have observed B. terrestris collecting cucurbit pollen in open fields. Therefore, B. terrestris may avoid collecting Cucurbita pollen, since as a generalist species it can visit alternative, more easily obtainable (in open field settings) or more desirable pollen. Combining this empirical data on Cucurbita pepo nectar and pollen with model simulations using the novel bumblebee model Bumble-BEEHAVE (Becher and Twiston-Davies et al. 2018), showed that populations of B. terrestris can only benefit from the transient nectar source of $C$. pepo if alternative floral resources (particularly pollen) are also available to fulfil bees' nutritional requirements in space and time (Knapp et al. 2018).

The complexity of pollinator-supporting practices can become further complicated when species-level responses are taken into consideration. For example, Apis spp. are less likely to increase their colony size in response to pollinatorsupporting practices because their populations are artificially maintained by beekeepers (Tab. 4). Since previous research has shown that Cucurbita crops are primarily serviced by long range, generalist pollinators: $B$. impatiens and $A$. mellifera in the USA (Petersen et al. 20I4) and B. terrestris and $A$. mellifera in the UK (Knapp and Osborne 2017) increasing forage and nesting may be less important to cucurbit crops, particularly in already heterogeneous environments (Tab. 4). This highlights the need to match pollinator-supportive management practices with the surrounding landscape and crops' individual requirements for pollination, since an increase in pollinator abundance and/or species richness may not necessarily be required for yield to be improved (Kleijn et al. 2015; Winfree et al. 2015). However, relying on a few generalist species for pollination services may be risky as any declines in their populations are also likely to affect specialist and/ or less common bee species which may also be effective pollinators.

\section{Value of pollination to growers}

Quantifying the economic value of pollination can be useful for informing decision making at farm and policy levels (Hanley et al. 20I4). Differentiating between the economic value of a crop's dependence on insect pollination and its pollination deficit will show the economic benefit of increasing pollinator populations as well as the economic cost that a decline in pollinator populations may have. Consequently, quantifying the economics of pollination is a fundamental way for growers to understand the implications that changes in pollinator populations may have on their yield and economic return. Economic valuations in the Cucurbita pepo variety 'Tosca' showed that whilst $56 \%$ of fruit set could be achieved via parthenocarpy, the total economic value of insect pollination to production was estimated to be worth approximately $£ 3,398 /$ ha (Knapp \& Osborne 2017). However, this economic valuation was based on the pollinator dependency and pollination deficit of just one Cucurbita pepo variety, thus inter-variety differences in pollinator dependence, or site-specific levels of pollination deficit may increase or decrease this economic value. An analogous example of this comes from apple crops: Malus domestica in the UK, where the variety 'Cox' is estimated to have a pollination deficit of $£ I 46 /$ ha, compared to the variety 'Gala' which had a much higher pollination deficit of $£ 6,459 /$ ha (Garratt et al. 2013). This is because 'Gala' is more pollinator-dependent and has a larger pollination deficit due to high yields from handpollinated flowers, compared to 'Cox'. Whilst economic valuations are based on relatively simple estimates of pollinator dependence, pollination levels, and growing practices, which may not be representative of a larger spatial scale, they do clearly demonstrate the importance of pollinators to crop production (Gallai et al. 2009).

It would be useful to know how growers of different species of pollinator-dependent crops perceive pollination in relation to their crops' level of pollinator dependence, as well as how the different factors affecting fruit set are prioritised in farm management, relative to the empirical evidence. A social survey of growers would tell us how their attitudes 


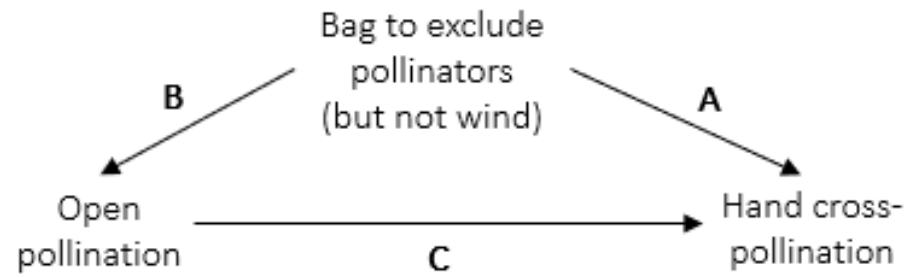

\begin{tabular}{|c|c|c|c|c|c|c|c|}
\hline & & & $\begin{array}{l}\text { Insects } \\
\text { required? }\end{array}$ & $\begin{array}{l}\text { Existing } \\
\text { pollinators } \\
\text { adequate? }\end{array}$ & $\begin{array}{l}\text { Loss of } \\
\text { insects } \\
\text { may } \\
\text { lower } \\
\text { yields? }\end{array}$ & $\begin{array}{l}\text { Symptomatic } \\
\text { yields }\end{array}$ & $\begin{array}{l}\text { Suggested } \\
\text { pollination } \\
\text { management }\end{array}$ \\
\hline $\begin{array}{l}\text { Increase } \\
\text { at } \mathbf{A}\end{array}$ & $\underset{\text { No }}{\longrightarrow}$ & $\begin{array}{l}\text { Wind or auto- } \\
\text { pollination } \\
\text { adequate: no } \\
\text { insect } \\
\text { pollinators } \\
\text { required }\end{array}$ & No & - & - & $\begin{array}{l}\text { Seedless } \\
\text { fruits, yield } \\
\text { may still } \\
\text { improve } \\
\text { with } \\
\text { pollination. }\end{array}$ & $\begin{array}{l}\text { None needed, } \\
\text { parthenocarpic } \\
\text { cultivars used. }\end{array}$ \\
\hline $\begin{array}{l}\text { Yes } \\
\text { Increase } \\
\text { at B } \\
\text { Yes }\end{array}$ & $\underset{\mathrm{No}}{\longrightarrow} \stackrel{\mathrm{P}}{\mathrm{p}}$ & $\begin{array}{l}\text { Insect } \\
\text { pollinators } \\
\text { are needed } \rightarrow \\
\text { but absent }\end{array}$ & Yes & No & Yes & No fruits & $\begin{array}{l}\text { Pollinator } \\
\text { management } \\
\text { necessary, } \\
\text { option A: } \\
\text { Improve } \\
\text { pollinator } \\
\text { habitat, option } \\
\text { B: Use } \\
\text { managed bees. }\end{array}$ \\
\hline $\begin{array}{l}\text { Increase } \\
\text { at C }\end{array}$ & $\underset{\text { No }}{\mathrm{a}}$ & $\begin{array}{l}\text { Insect } \\
\text { pollinators } \\
\text { are needed, } \rightarrow \\
\text { and at } \\
\text { present, }\end{array}$ & Yes & Yes & Yes & $\begin{array}{l}\text { Many } \\
\text { seeded fruits }\end{array}$ & $\begin{array}{l}\text { Maintain } \\
\text { existing } \\
\text { pollinator } \\
\text { management. }\end{array}$ \\
\hline Yes & . & $\begin{array}{l}\text { Insect } \\
\text { pollinators } \\
\text { are needed } \rightarrow \\
\text { to maximise } \\
\text { yield }\end{array}$ & Yes & No & Yes & $\begin{array}{l}\text { Some } \\
\text { seeded fruits }\end{array}$ & $\begin{array}{l}\text { Pollinator } \\
\text { management } \\
\text { necessary, } \\
\text { option A: } \\
\text { Improve } \\
\text { pollinator } \\
\text { habitat, option } \\
\text { B: Use } \\
\text { managed bees. }\end{array}$ \\
\hline
\end{tabular}

FIGURE 3. Experimental process for a grower to discover the extent to which their cucurbit variety depends on pollination, and to investigate the adequacy of the existing pollinator community (adapted from Corbet et al. 199I).

towards pollinators correspond to their management actions and if growers identify any key barriers or opportunities to integrating pollination in their management for optimal crop yields. To date, farmer surveys have mostly focused on ecosystem services in isolation, although see Andersson et al. (2015). For example, surveys identified that achieving consistent and reliable pollination is a priority for $V$. corymbosum growers in Michigan and Florida in the USA (Integrated Crop Pollination Project, 2016). However, there is no way of knowing how much of a priority pollination is to these growers, relative to all the other factors which may affect yield such as pest control or soil quality. This information is critical to understand the likelihood of growers adapting 
existing, or adopting new, sustainable pollination management.

Since growers are unlikely to know pollination rates for their crops and therefore their potential pollination deficit, it would be useful to develop a predictive model to determine if managed pollinators are required and/ or if longer-term pollinator habitat creation is warranted. Although other pollination service models exist (e.g. Olsson et al. 2015), BEESTEWARD (www.beehave-model.net) has an interface which already enables users to simulate the effects that different management options, such as wild flower strips will have on bumblebee population dynamics and pollination services.

\section{Conclusion}

These studies highlight the importance of pollination for improving cucurbit yield, despite pollinator behaviour, pollen deposition on stigmas, and pollinators' contribution to yield varying across cucurbit species and study. From a biological view, this may be due to the relative attractiveness of flowers, and/or the pollinator dependency of the cucurbit species, whilst from a management view, the spatial and temporal context of study sites could affect the abundance and richness of wild pollinator species. Nonetheless, these accounts of cucurbit pollination demonstrate that wild bee species such as B. terrestris, B. impatiens and Eucera spp. are frequently able to fulfil the pollination requirements of multiple cucurbit species. Sufficient abundance of these wild bee species may be why in several cases, the addition of managed pollinator species had little or no effect on increasing yield. The provision of additional floral resources at both field and farm scales may help to encourage pollination of cucurbit species whilst supporting pollinators' nutritional requirements beyond those already provided by the cucurbit crop.

These findings extend beyond cucurbit systems (Fig. 3) to demonstrate how understanding a crop's requirement for pollination and how pollinators vary spatially and temporally in the landscape can aid growers in their decision making about what varieties and sites should be used. In doing so, growers may be able to increase their agricultural resilience and further their economic advantage. Nonetheless, further work is needed to understand how other environmental factors interact with pollination to influence fruit set so that growers can prioritise key regulating services in their management for optimal crop yields.

\section{ACKNOWLEDGEMENTS}

We would like to thank Benjamin Phillips and Lewis Bartlett for their valuable feedback on this manuscript. This work was funded as part of $\mathrm{PhD}$ studentship (CPII8) sponsored by the Agriculture and Horticulture Development Board, UK. JO was also supported by a grant from the Natural Environment Research Council UK [NE/J0I4893/I].

\section{APPENDICES}

Additional supporting information may be found in the online version of this article:

APPENDIX I. Pollen transfer in monoecious cucurbits.

\section{REFERENCES}

Adamson NL, Roulston TH, Fell RD, Mullins DE (2012) From April to August-Wild Bees Pollinating Crops Through the Growing Season in Virginia, USA. Environmental Entomology 4I:8I3-82I.

Adler LS, Hazzard R V (2009) Comparison of perimeter trap crop varieties: effects on herbivory, pollination, and yield in butternut squash. Environmental entomology 38:207-215.

Agriculture and Horticulture Developement Board (2013) Crop Walkers' Guide - Outdoor Cucurbits.

Ali M, Saeed S, Sajjad A, Akbar A (2015) Linking Pollination Effectiveness and Interspecific Displacement Success in Bees. Neotropical Entomology 44:I0I-I08. [online] URL: http://link.springer.com/I0.I007/sI3744-0I4-0259-0

Ali M, Saeed S, Sajjad A, Bashir MA (20I4) Exploring the Best Native Pollinators for Pumpkin (Cucurbita pepo) Production in Punjab, Pakistan. Pakistan Journal of Zoology 46:53I-539.

Andersson E, Nykvist B, Malinga R, Jaramillo F, Lindborg R (2015) A social - ecological analysis of ecosystem services in two different farming systems. Ambio 44:I02-II2.

Artz DR, Hsu CL, Nault BA (201I) Influence of honey bee, Apis mellifera, hives and field size on foraging activity of native bee species in pumpkin fields. Environmental Entomology 40:I I44II58

Artz D, Nault B (201I) Performance of Apis mellifera, Bombus impatiens, and Peponapis pruinosa (Hymenoptera: Apidae) as pollinators of pumpkin. Journal of Economic Entomology I04:II53-II6I.

Barber NA, Adler LS, Bernardo HL (2011) Effects of above- and belowground herbivory on growth, pollination, and reproduction in cucumber. Oecologia 165:377-386.

Batáry P, Báldi A, Kleijn D, Tscharntke T (20II) Landscapemoderated biodiversity effects of agri-environmental management: a meta-analysis. Proceedings of the Royal Society B 278:18941902.

Bates DM, Robinson RW, Jeffrey C (1990) Biology and Utilization of the Cucurbitaceae. Comstock Publishing Associates, Ithaca and London.

Becher MA, Twiston-Davies G, Penny TD, Goulson D, Rotheray EL, Osborne JL (2018) Bumble-BEEHAVE: A systems model for exploring multifactorial causes of bumblebee decline at individual, colony, population and community level. Journal of Applied Ecology 55:2790-280I.

Bisognin DA (2002) Origin and evolution of cultivated cucurbits. Ciência Rural 32:715-723.

Blaauw BR, Isaacs R (20I4) Flower plantings increase wild bee abundance and the pollination services provided to a pollinationdependent crop. Journal of Applied Ecology 5 I:890-898.

Bomfim I, Souza de Aragão F, Walters S (2016) Pollination in Cucurbit Crops. In: Cucurbits: History, Nomenclature, Taxonomy, and Reproductive Growth.pp I8I-200.

Bommarco R, Kleijn D, Potts SG (2013) Ecological intensification: Harnessing ecosystem services for food security. Trends in Ecology and Evolution 28:230-238.

Bretagnolle V, Gaba S (2015) Weeds for bees? A review. Agronomy for Sustainable Development 35:89I-909.

Campbell JW, Kimmel CB, Bammer M, Stanley-Stahr C, Daniels JC, Ellis JD (2018) Managed and Wild Bee Flower Visitors and Their Potential Contribution to Pollination Services of Low-Chill Highbush Blueberry (Vaccinium corymbosum L.; Ericales: Ericaceae). Journal of Economic Entomology:I-6. 
TABLE 4. Effect of pollinator-supporting practices on various metrics of pollination in cucurbits. Effects of these agricultural practices were classed as 'positive', 'negative' or 'none' based on the direction of the relationship and statistical significance $(\mathrm{P}<0.05)$ presented in the original studies.

\begin{tabular}{|c|c|c|c|c|c|}
\hline Species & $\begin{array}{l}\text { Sex expression, } \\
\text { breeding system }\end{array}$ & $\begin{array}{l}\text { Study } \\
\text { location }\end{array}$ & Level of pollination & Key findings & Citation \\
\hline $\begin{array}{l}\text { Citrullus } \\
\text { lanatus }\end{array}$ & $\begin{array}{l}\text { Monoecious } \\
\text { varieties } \\
\text { assumed to be } \\
\text { dependent on } \\
\text { insect } \\
\text { pollination. }\end{array}$ & $\begin{array}{l}\text { Field } \\
\text { study, } \\
\text { USA }\end{array}$ & $\begin{array}{l}\text { Pollination deficit not } \\
\text { quantified. }\end{array}$ & $\begin{array}{l}\text { Insecticide use had no effect on pollen } \\
\text { deposition. } \\
\text { Amount of natural habitat surrounding } \\
\text { a site had a positive effect on pollen } \\
\text { deposition. } \\
\text { Field size and organic farming had no } \\
\text { effect on pollen deposition. }\end{array}$ & $\begin{array}{l}\text { (Kremen } \\
\text { et al. } \\
2004)\end{array}$ \\
\hline $\begin{array}{l}\text { Cucumis } \\
\text { melo and } \\
\text { Citrullus } \\
\text { lanatus }\end{array}$ & $\begin{array}{l}\text { Monoecious } \\
\text { variety, assumed } \\
\text { to be dependent } \\
\text { on insect } \\
\text { pollination. }\end{array}$ & $\begin{array}{l}\text { Field } \\
\text { study, } \\
\text { USA }\end{array}$ & $\begin{array}{l}\text { Pollination unlikely } \\
\text { limiting yield - visitation } \\
\text { from wild bees } 62 \% \text { and } \\
\text { fields supplemented with } \\
\text { A. mellifera. }\end{array}$ & $\begin{array}{l}\text { Flowering weeds had no effect on bee } \\
\text { visitation to crop flowers. }\end{array}$ & $\begin{array}{l}\text { (Winfree } \\
\text { et al. } \\
2008 \text { ) }\end{array}$ \\
\hline $\begin{array}{l}\text { Cucumis } \\
\text { sativus }\end{array}$ & $\begin{array}{l}\text { Monoecious } \\
\text { variety, some } \\
\text { parthenocarpy } \\
\text { observed in no } \\
\text { pollination } \\
\text { controls }\end{array}$ & $\begin{array}{l}\text { Field } \\
\text { study, } \\
\text { Indonesi } \\
\text { a }\end{array}$ & $\begin{array}{l}\text { Pollination deficit not } \\
\text { quantified. Only yield } \\
\text { from none and open } \\
\text { pollinated flowers. }\end{array}$ & $\begin{array}{l}\text { Fertilisation had a positive effect on } \\
\text { fruit weight and bee visitation to crop } \\
\text { flowers. } \\
\text { Insecticide use had no effect on fruit } \\
\text { weight and bee visitation to crop } \\
\text { flowers. } \\
\text { Herbicide use and manual weeding had } \\
\text { no effect on fruit weight and bee } \\
\text { visitation to crop flowers. }\end{array}$ & $\begin{array}{l}\text { Motzke } \\
\text { et al. } \\
\text { 20I5) }\end{array}$ \\
\hline $\begin{array}{l}\text { Cucumis } \\
\text { sativus }\end{array}$ & $\begin{array}{l}\text { Monoecious } \\
\text { variety, assumed } \\
\text { to be dependent } \\
\text { on insect } \\
\text { pollination. }\end{array}$ & $\begin{array}{l}\text { Field } \\
\text { study, } \\
\text { USA }\end{array}$ & $\begin{array}{l}\text { Pollination deficit not } \\
\text { quantified. Fields were } \\
\text { supplemented with } A \text {. } \\
\text { mellifera. }\end{array}$ & $\begin{array}{l}\text { Amount of natural habitat surrounding } \\
\text { a site had a positive effect on wild bee } \\
\text { abundance and richness. }\end{array}$ & $\begin{array}{l}\text { (Lowenste } \\
\text { in \& } \\
\text { Huseth } \\
\text { 2012) }\end{array}$ \\
\hline $\begin{array}{l}\text { Cucurbita } \\
\text { maxima }\end{array}$ & $\begin{array}{l}\text { Monoecious } \\
\text { variety, assumed } \\
\text { to be dependent } \\
\text { on insect } \\
\text { pollination. }\end{array}$ & $\begin{array}{l}\text { Field } \\
\text { study, } \\
\text { Germany }\end{array}$ & $\begin{array}{l}\text { Pollination not limiting } \\
\text { to yield - more pollen } \\
\text { grains deposited } \\
(\sim \text { II,000) then required } \\
\text { for fruit set }(\sim 2,500) .\end{array}$ & $\begin{array}{l}\text { Amount of cropland surrounding a } \\
\text { site had a negative effect on Bombus } \\
\text { spp. visitation to crop flowers }\end{array}$ & $\begin{array}{l}\text { (Pfister et } \\
\text { al. 2018) }\end{array}$ \\
\hline $\begin{array}{l}\text { Cucurbita } \\
\text { moschata }\end{array}$ & $\begin{array}{l}\text { Monoecious } \\
\text { variety, assumed } \\
\text { to be dependent } \\
\text { on insect } \\
\text { pollination. }\end{array}$ & $\begin{array}{l}\text { Field } \\
\text { study, } \\
\text { USA }\end{array}$ & $\begin{array}{l}\text { Pollination not limiting } \\
\text { to yield- visitation from } \\
\text { wild bees was } 87 \% \text {. }\end{array}$ & $\begin{array}{l}\text { Trap crops had no effect on fruit } \\
\text { weight or bee visitation to crop } \\
\text { flowers. }\end{array}$ & $\begin{array}{l}\text { (Adler \& } \\
\text { Hazzard } \\
2009)\end{array}$ \\
\hline $\begin{array}{l}\text { Cucurbita } \\
\text { moschata }\end{array}$ & $\begin{array}{l}\text { Monoecious } \\
\text { variety, assumed } \\
\text { to be dependent } \\
\text { on insect } \\
\text { pollination. }\end{array}$ & $\begin{array}{l}\text { Field } \\
\text { study, } \\
\text { USA }\end{array}$ & $\begin{array}{l}\text { Pollination not limiting } \\
\text { to yield- no difference in } \\
\text { yield between hand- and } \\
\text { open- pollinated flowers }\end{array}$ & $\begin{array}{l}\text { Trap crops had no effect on fruit } \\
\text { weight or bee visitation to crop } \\
\text { flowers, but did reduce pest damage in } \\
\text { the focal crop. }\end{array}$ & $\begin{array}{l}\text { (Cavanagh } \\
\text { et al. } \\
2010)\end{array}$ \\
\hline $\begin{array}{l}\text { Cucurbita } \\
\text { pepo }\end{array}$ & $\begin{array}{l}\text { Monoecious } \\
\text { variety, some } \\
\text { parthenocarpy } \\
\text { observed in no } \\
\text { pollination } \\
\text { controls }\end{array}$ & $\begin{array}{l}\text { Field } \\
\text { study, } \\
\text { UK }\end{array}$ & $\begin{array}{l}\text { Pollination deficit not } \\
\text { quantified. }\end{array}$ & $\begin{array}{l}\text { Flowering weeds had a positive effect } \\
\text { on } B \text {. terrestris abundance and no } \\
\text { effect on } A \text {. mellifera abundance. } \\
\text { Amount of natural habitat surrounding } \\
\text { a site had a negative effect on } A \text {. } \\
\text { mellifera abundance and no effect on } \\
B . \text { terrestris abundance. } \\
\text { Field size had no effect on } A \text {. mellifera } \\
\text { or } B \text {. terrestris abundance. }\end{array}$ & $\begin{array}{l}\text { (Knapp et } \\
\text { al. 2019) }\end{array}$ \\
\hline
\end{tabular}


Tab. 4 continued

\begin{tabular}{|c|c|c|c|c|c|}
\hline Species & $\begin{array}{l}\text { Sex expression, } \\
\text { breeding system }\end{array}$ & $\begin{array}{l}\text { Study } \\
\text { location }\end{array}$ & Level of pollination & Key findings & Citation \\
\hline $\begin{array}{l}\text { Cucurbita } \\
\text { pepo }\end{array}$ & $\begin{array}{l}\text { Monoecious } \\
\text { variety, assumed } \\
\text { to be dependent } \\
\text { on insect } \\
\text { pollination. }\end{array}$ & $\begin{array}{l}\text { Field } \\
\text { study, } \\
\text { USA }\end{array}$ & $\begin{array}{l}\text { Pollination unlikely } \\
\text { limiting yield - visitation } \\
\text { from wild bees } 52 \% \text { and } \\
\text { fields supplemented with } \\
\text { A. mellifera. }\end{array}$ & $\begin{array}{l}\text { Floral strips had no effect on bee } \\
\text { visitation to crop flowers or pollen } \\
\text { deposition. } \\
\text { Landscape diversity surrounding a site } \\
\text { had a positive effect on bee visitation } \\
\text { and pollen deposition. }\end{array}$ & $\begin{array}{l}\text { (Phillips } \\
\& \\
\text { Gardiner } \\
\text { 20I5) }\end{array}$ \\
\hline $\begin{array}{l}\text { Cucurbita } \\
\text { pepo }\end{array}$ & $\begin{array}{l}\text { Monoecious } \\
\text { variety, assumed } \\
\text { to be dependent } \\
\text { on insect } \\
\text { pollination. }\end{array}$ & $\begin{array}{l}\text { Field } \\
\text { study, } \\
\text { USA }\end{array}$ & $\begin{array}{l}\text { Pollination unlikely } \\
\text { limiting yield as bee } \\
\text { visitation was determined } \\
\text { to be sufficiently high } \\
\text { and some fields } \\
\text { supplemented with } A \text {. } \\
\text { mellifera }\end{array}$ & $\begin{array}{l}\text { Soil clay content had a negative effect } \\
\text { on } P \text {. pruinosa abundance. } \\
\text { Tillage had no effect on } P \text {. pruinosa } \\
\text { abundance. } \\
\text { Amount of natural habitat surrounding } \\
\text { a site had no effect on } P \text {. pruinosa } \\
\text { abundance. }\end{array}$ & $\begin{array}{l}\text { (Julier \& } \\
\text { Roulston } \\
\text { 2009) }\end{array}$ \\
\hline $\begin{array}{l}\text { Cucurbita } \\
\text { pepo }\end{array}$ & $\begin{array}{l}\text { Monoecious } \\
\text { variety, assumed } \\
\text { to be dependent } \\
\text { on insect } \\
\text { pollination. }\end{array}$ & $\begin{array}{l}\text { Field } \\
\text { study, } \\
\text { China. }\end{array}$ & $\begin{array}{l}\text { Pollination unlikely } \\
\text { limiting to yield - at } \\
\text { most sites more pollen } \\
\text { grains deposited then } \\
\text { required for fruit set. }\end{array}$ & $\begin{array}{l}\text { Amount of natural habitat surrounding } \\
\text { a site had a positive effect on pollen } \\
\text { deposition and Bombus spp. visitation } \\
\text { but no effect on } A \text {. cerana visitation to } \\
\text { crop flowers. }\end{array}$ & $\begin{array}{l}\text { (Xie \& An } \\
\text { 20I4) }\end{array}$ \\
\hline $\begin{array}{l}\text { Cucurbita } \\
\text { pepo }\end{array}$ & $\begin{array}{l}\text { Monoecious } \\
\text { variety assumed } \\
\text { to be dependent } \\
\text { on pollination. }\end{array}$ & $\begin{array}{l}\text { Field } \\
\text { study, } \\
\text { USA }\end{array}$ & $\begin{array}{l}\text { Pollination deficit not } \\
\text { quantified. }\end{array}$ & $\begin{array}{l}\text { Landscape diversity surrounding a site } \\
\text { had a positive effect Bombus spp. } \\
\text { visitation and fruit weight. }\end{array}$ & $\begin{array}{l}\text { (Petersen } \\
\& \text { Nault } \\
2014)\end{array}$ \\
\hline $\begin{array}{l}\text { Cucurbita } \\
\text { spp. }\end{array}$ & $\begin{array}{l}\text { Monoecious } \\
\text { varieties } \\
\text { assumed to be } \\
\text { dependent on } \\
\text { insect } \\
\text { pollination. }\end{array}$ & $\begin{array}{l}\text { Field } \\
\text { study, } \\
\text { USA }\end{array}$ & $\begin{array}{l}\text { Pollination deficit not } \\
\text { quantified. }\end{array}$ & $\begin{array}{l}\text { Pesticide use had no effect on Bombus } \\
\text { spp. or } P \text {. pruinosa visitation to crop } \\
\text { flowers. } \\
\text { Tillage had a negative effect on } P \text {. } \\
\text { pruinosa visitation to crop flowers and } \\
\text { no effect on } B \text {. impatiens visitation to } \\
\text { crop flowers. }\end{array}$ & $\begin{array}{l}\text { (Shuler et } \\
\text { al. 2005) }\end{array}$ \\
\hline
\end{tabular}

Canto-Aguilar A, Veterinaria M (2000) Importance of conserving alternative pollinators: assessing the pollination efficiency of the squash bee, Peponapis limitaris in Cucurbita moschata (Cucurbitaceae). Journal of Insect Conservation 4:203-2I0.

Carvell C, Osborne JL, Bourke AFG, Freeman SN, Pywell RF, Heard MS (2015) Bumble bee species' responses to a targeted conservation measure depend on landscape context and habitat quality. Ecological Applications 2I:1760-I77I.

Cavanagh AF, Adler LS, Hazzard R V. (2010) Buttercup Squash Provides a Marketable Alternative to Blue Hubbard as a Trap Crop for Control of Striped Cucumber Beetles (Coleoptera: Chrysomelidae). Environmental Entomology 39:1953-1960. [online] URL: https://academic.oup.com/ee/articlelookup/doi/10.1603/EN10056

Corbet SA, Williams IH, Osborne JL (I99I) Bees and the pollination of crops and wild flowers in the european community. Bee World 72:47-59.

Dicks L V., Baude M, Roberts SPM, Phillips J, Green M, Carvell C (2015) How much flower-rich habitat is enough for wild pollinators? Answering a key policy question with incomplete knowledge. Ecological Entomology 40:22-35. [online] URL: http://doi.wiley.com/I0.IIII/een.I2226

Free JB (1993) Insect pollination of crops. Academic Press Inc, London.
Gallai N, Salles JM, Settele J, Vaissière BE (2009) Economic valuation of the vulnerability of world agriculture confronted with pollinator decline. Ecological Economics 68:810-82I.

Garantonakis N, Varikou K, Birouraki A, Edwards M, Kalliakaki V, Andrinopoulos F (2016) Comparing the pollination services of honey bees and wild bees in a watermelon field. Scientia Horticulturae 204:I38-I44. [online] URL: http://www.sciencedirect.com/science/article/pii/S03044238I $\underline{6301716}$

Garibaldi LA, Steffan-Dewenter I, Kremen C, Morales JM, Bommarco R, Cunningham SA, Carvalheiro LG, Chacoff NP, Dudenhöffer JH, Greenleaf SS, Holzschuh A, Isaacs R, Krewenka K, Mandelik Y, Mayfield MM, Morandin LA, Potts SG, Ricketts TH, Szentgyörgyi H, Viana BF, Westphal C, Winfree R, Klein AM (20II) Stability of pollination services decreases with isolation from natural areas despite honey bee visits. Ecology Letters I4:1062-1072.

Garratt MPD, Breeze TD, Jenner N, Polce C, Biesmeijer JC, Potts SG (2013) Avoiding a bad apple: insect pollination enhances fruit quality and economic value. Agriculture, Ecosystems and Environment I84:34-40. [online] URL: http://dx.doi.org/ $\underline{10.1016 / \text { j.agee.2013.10.032 }}$ 
Gingras D, Gingras J, DeOliveira D (1999) Visits of honeybees (Hymenoptera: Apidae) and their effects on cucumber yields in the field. Journal of Economic Entomology 92:435-438.

Goodell K, Thomson JD (2007) Influence of bee species (Hymenoptera: Apiformes) with contrasting behaviors on pollen movement in a mustard, Brassica rapa (Brassicaceae) and the muskmelon Cucumis melo (Cucurbitaceae). Entomologia Generalis 29:237-252.

Hanley N, Breeze TD, Ellis C, Goulson D (20I4) Measuring the economic value of pollination services: Principles, evidence and knowledge gaps. Ecosystem Services I4:I-9. [online] URL: http://linkinghub.elsevier.com/retrieve/pii/S22I204I6I400II $\underline{56}$

Heard MS, Carvell C, Carreck NL, Rothery P, Osborne JL, Bourke AFG (2007) Landscape context not patch size determines bumblebee density on flower mixtures sown for agri-environment schemes. Biology Letters 3:638-64I.

Hladun KR, Adler LS (2009) Influence of leaf herbivory, root herbivory, and pollination on plant performance in Cucurbita moschata. Ecological Entomology 34:I44-I52.

Hoehn P, Tscharntke T, Tylianakis JM, Steffan-Dewenter I (2008) Functional group diversity of bee pollinators increases crop yield. Proceedings. Biological sciences / The Royal Society 275:22832291.

Holzschuh A, Dainese M, Gonzlez-Varo J, Mudri-Stojnic S, Riedinger V, Rundlof M, Scheper J, Wickens J, Wickens V, Bommarco R, Kleijn D, Potts S, Roberts S, Smith HG, Montserrat V, Vujic A, Steffan-Dewenter I (2016) Mass-flowering crops dilute pollinator abundance in agricultural landscapes across Europe. Ecology Letters I9:1228-I236.

Hurd PD, Linsley EG, Michelbacher AD (1974) Ecology of the squash and gourd bee, Peponapis pruinosa, on cultivated cucurbits in California (Hymenoptera: Apoidea). Smithsonian Contributions to Zoology:I-I7.

Hurd P, Linsley G, Whitaker T (I97I) Squash and Gourd Bees (Peponapis, Xenoglossa) and the Origin of the Cultivated Cucurbita. Evolution 25:218-234.

Integrated Crop Pollination Project (2016) Florida Blueberry Grower Survey Report.

Julier HE, Roulston TH (2009) Wild bee abundance and pollination service in cultivated pumpkins: farm management, nesting behavior and landscape effects. Journal of Economic Entomology 102:563-573.

Kleijn D, Winfree R, Bartomeus I, Carvalheiro LG, Henry M, Isaacs R, Klein A-M, Kremen C, M'Gonigle LK, Rader R, Ricketts TH, Williams NM, Adamson NL, Ascher JS, Báldi A, Batáry P, Benjamin F, Biesmeijer JC, Blitzer EJ, Bommarco R, Brand MR, Bretagnolle V, Button L, Cariveau DP, Chifflet R, Colville JF, Danforth BN, Elle E, Garratt MPD, Herzog F, Holzschuh A, Howlett BG, Jauker F, Jha S, Knop E, Krewenka KM, Le Féon V, Mandelik Y, May EA, Park MG, Pisanty G, Reemer M, Riedinger V, Rollin O, Rundlöf M, Sardiñas HS, Scheper J, Sciligo AR, Smith HG, Steffan-Dewenter I, Thorp R, Tscharntke T, Verhulst J, Viana BF, Vaissière BE, Veldtman R, Westphal C, Potts SG (2015) Delivery of crop pollination services is an insufficient argument for wild pollinator conservation. Nature Communications 6:74I4

Klein A-MM, Vaissière BE, Cane JH, Steffan-Dewenter I, Cunningham SA, Kremen C, Tscharntke T (2007) Importance of pollinators in changing landscapes for world crops. Proceedings of the Royal Society B: Biological Sciences 274:303-313.

Knapp JL, Bartlett LJ, Osborne JL (2016) Re-evaluating strategies for pollinator-dependent crops: How useful is parthenocarpy? Journal of Applied Ecology 54:1-9.
Knapp JL., Becher MA., Rankin CC, Osborne JL (2018) Bombus terrestris in a mass-flowering pollinator-dependent crop: A mutualistic relationship? Ecology and Evolution

Knapp JL, Osborne JL (2017) Courgette Production: Pollination Demand, Supply, and Value. Journal of Economic Entomology I I0:1973-I979.

Knapp JL, Shaw R., Osborne JL (2019) Pollinator visitation to mass-flowering courgette and co-flowering wild flowers: implications for pollination and pollinator conservation. Basic and Applied Ecology

Kouonon LC, Jacquemart AL, Zoro Bi AI, Bertin P, Baudoin JP, Dje Y (2009) Reproductive biology of the andromonoecious Cucumis melo subsp. agrestis (Cucurbitaceae). Annals of Botany I04:1 I29_ II39.

Kremen C, Williams NM, Bugg RL, Fay JP, Thorp RW (2004) The area requirements of an ecosystem service: crop pollination by native bee communities in California. Ecology Letters 7:1 I09III9.

Kumar R (2016) Cucurbits: History, Nomenclature, Taxonomy, and Reproductive Growth. In: Pessarakli M (ed) Handbook of Cucurbits: Growth, Cultural Practices, and Physiology.pp 3-22.

Kurtar E. (2003) An investigation of parthenocarpy in some summer squash (Cucurbita pepo L.) cultivars. Journal of Agronomy 2:209_ $2 \mathrm{I} 3$.

Lau Tak-Cheung, Stephenson A (1993) Effects of soil nitrogen on pollen production, pollen grain size, and pollen performance in Cucurbita pepo (Cucurbitaceae). American Journal of Botany 80:763-768.

Lowenstein DM, Huseth AS (2012) Response of Wild Bees (Hymenoptera: Apoidea: Anthophila) to Surrounding Land Cover in Wisconsin Pickling Cucumber. Environmental Entomology 4I:532-540.

Mader E, Spivak M, Evans E (2010) Managing Alternative Pollinators: A Handbook for Beekeepers, Growers, and Conservationists. NRAES, New York.

Martínez C, Manzano S, Megías Z, Garrido D, Picó B, Jamilena M (2013) Involvement of ethylene biosynthesis and signalling in fruit set and early fruit development in zucchini squash (Cucurbita pepo L.). BMC plant biology I3:I-I4.

Martínez C, Manzano S, Megías Z, Garrido D, Picó B, Jamilena M (20I4) Sources of parthenocarpy for zucchini breeding: relationship with ethylene production and sensitivity. Euphytica 200:349-362.

Mathewson JA (1968) Nest Construction and Life History of the Eastern Cucurbit Bee, Peponapis pruinosa (Hymenoptera: Apoidea). Journal of the Kansas Entomological Society 4I:255$26 \mathrm{I}$.

McCreight J, Staub J, Wehner T, Dhillon N (2013) Gone Global: Familiar and Exotic Cucurbits Have Asian Origins. HortScience 48:1078-1089

Melathopoulos AP, Cutler GC, Tyedmers P (2015) Where is the value in valuing pollination ecosystem services to agriculture? Ecological Economics 109:59-70. [online] URL http://dx.doi.org/10.1016/j.ecolecon.2014.11.007

Metcalf RL, Rhodes AM, Metcalf RA, Ferguson J, Metcalf ER, Lu P (1982) Cucurbitacin Contents and Diabroticite (Coleoptera Chrysomelidae) feeding upon Cucurbita spp. Entomological Society of America II:93I-937.

Motzke I, Tscharntke T, T. W, Klein A (2015) Pollination mitigates cucumber yield gaps more than pesticide and fertilizer use in tropical smallholder gardens. Journal of Applied Ecology 52:26I269. 
Ne'eman G, Jürgens A, Newstrom-Lloyd L, Potts SG, Dafni A (2010) A framework for comparing pollinator performance: Effectiveness and efficiency. Biological Reviews 85:435-45I.

Nicodemo D, Malheiros EB, Jong D De, Couto RHN (2013) Enhanced production of parthenocarpic cucumbers pollinated with stingless bees and Africanized honey bees in greenhouses. Semina:Ciencias Agrarias 34:3625-3634.

Njoroge GN, Gemmill B, Bussmann R, Newton LE, Ngumi VM (20I0) Diversity and efficiency of wild pollinators of watermelon (Citrullus lanatus (Thunb.) Mansf.) at Yatta (Kenya). Journal of Applied Horticulture I2:35-4I.

Olsson O, Bolin A, Smith HG, Lonsdorf E V. (2015) Modeling pollinating bee visitation rates in heterogeneous landscapes from foraging theory. Ecological Modelling 316:133-I43.

Osborne JL, Martin AP, Shortall CR, Todd AD, Goulson D, Knight ME, Hale RJ, Sanderson R a. (2008) Quantifying and comparing bumblebee nest densities in gardens and countryside habitats. Journal of Applied Ecology 45:784-792.

Petersen JD, Huseth AS, Nault BA (20I4) Evaluating pollination deficits in pumpkin production in New York. Plant-Insect Interactions:1247-I253.

Petersen J, Nault B (20I4) Landscape diversity moderates the effects of bee visitation frequency to flowers on crop production. Journal of Applied Ecology:1347-I356.

Petersen JD, Reiners S, Nault B (2013) Pollination services provided by bees in pumpkin fields supplemented with either Apis mellifera or Bombus impatiens or not supplemented. PLoS ONE 8:I-8.

Pfister SC, Eckerter PW, Krebs J, Cresswell JE, Schirmel J, Entling MH (2018) Dominance of cropland reduces the pollen deposition from bumble bees. Scientific Reports 8:I-8.

Phillips BW, Gardiner MM (2015) Use of video surveillance to measure the influences of habitat management and landscape composition on pollinator visitation and pollen deposition in pumpkin (Cucurbita pepo) agroecosystems. PeerJ 3:eI342. [online] URL: https:// peerj.com/articles/I342

Pisanty G, Afik O, Wajnberg E, Mandelik Y (2015) Watermelon pollinators exhibit complementarity in both visitation rate and single-visit pollination efficiency. Journal of Applied Ecology 53:360-370.

Project ICP (2016) Michigan Blueberry Grower Survey Report.

Robinson RW (2000) Rationale and Methods for Producing Hybrid Cucurbit Seed. Journal of New Seeds I:49-67.

Robinson RW, Reiners S (1999) Parthenocarpy in summer squash. HortScience 34:715-7I7.

Rodriguez-Granados NY, Lemhemdi A, Choucha FA, Latrasse D, Benhamed M, Adnane B, Bendahmane A (2017) Sex Determination in Cucumis. In: Grumet R., Katzir N. G-MJ (ed) Genetics and Genomics of Cucurbitaceae, Plant Gene. Springer, Cham

Roldán-Serrano S, Guerra-Sanz JM (2005) Reward attractions of zucchini flowers (Cucurbita pepo L.) to bumblebees (Bombus terrestris L.). European Journal of Horticultural Science 70:23-28.

Scheper J, Holzschuh A, Kuussaari M, Potts SG, Rundlöf M, Smith HG, Kleijn D, Letters E (2013) Environmental factors driving the effectiveness of European agri-environmental measures in mitigating pollinator loss - a meta-analysis. Ecology Letters I6:912-920.

Shin YS, Park SD, Kim JH (2007) Influence of pollination methods on fruit development and sugar contents of oriental melon (Cucumis melo L. cv. Sagyejeol-Ggul). Scientia Horticulturae II $2: 388-392$.
Shuler RE, Roulston TH, Farris GE (2005) Farming practices influence wild pollinator populations on squash and pumpkin. Journal of Economic Entomology 98:790-795.

Stanghellini MS, Ambrose JT, Schulthcis JR (1998) Using commercial bumble bee colonies as backup pollinators for honey bees to produce cucumbers and watermelons. HortTechnology 8:588-590.

Stanghellini MS, Ambrose JT, Schultheis JR (2002) Diurnal activity, floral visitation and pollen deposition by honey bees and bumble bees on field-grown cucumber and watermelon. Journal of Apicultural Research 4I:27-34.

Stephenson AG, Devlin B, Horton JB (I988) The effects of seed number and prior fruit dominance on the pattern of fruit production in Cucurbita pepo (zucchini squash). Annals of Botany 62:653-661.

Tepedino V (198I) The Pollination Efficiency of the Squash Bee (Peponapis pruinosa) and the Honey Bee (Apis mellifera) on Summer Squash (Cucurbita pepo). Journal of the Kansas (Central States) Entomological Society 54:359-377.

Tscharntke T, Tylianakis JM, Rand TA, Didham RK, Fahrig L, Batáry P, Bengtsson J, Clough Y, Crist TO, Dormann CF, Ewers RM, Fründ J, Holt RD, Holzschuh A, Klein AM, Kleijn D, Kremen C, Landis DA, Laurance W, Lindenmayer D, Scherber C, Sodhi N, Steffan-Dewenter I, Thies C, van der Putten WH, Westphal C (2012) Landscape moderation of biodiversity patterns and processes - eight hypotheses. Biological Reviews 87:66I-685.

Vaissière BE, Vinson SB (1994) Pollen morphology and its effect on pollen collection by honey bees, apis mellifera L. (hymenoptera: Apidae), with special reference to upland cotton, gossypium hitsutum L. (malvaceae). Grana 33:128-I38.

Vidal MDG, Jong D De, Wien HC, Morse R a. (2006) Nectar and pollen production in pumpkin (Cucurbita pepo L.). Revista Brasileira de Botânica 29:267-273.

Vidal MDG, Jong D De, Wien HC, Morse R a. (2010) Pollination and fruit set in pumpkin (Cucurbita pepo) by honey bees. Revista Brasileira de Botânica 33:I06-II3.

Walters SA (2005) Honey bee pollination requirements for triploid watermelon. HortScience 40:1268-I270.

Walters A, Taylor B (2006) Effects of honey bee pollination on pumpkin fruit and seed yield. HortScience 4I:370-373.

Willis DS, Kevan PG (1995) Foraging Dynamics of Peponapis Pruinosa (Hymenoptera: Anthophoridae) on Pumpkin (Cucurbita Pepo) in Southern Ontario. The Canadian Entomologist I27:167I75.

Winfree R, Fox J, Williams NM, Reilly JR, Cariveau DP (2015) Abundance of common species, not species richness, drives delivery of a real-world ecosystem service. Ecology Letters 18:626-635. [online] URL: http://doi.wiley.com/I0.IIII/ele.I2424

Winfree R, Williams NM, Gaines H, Ascher JS, Kremen C (2008) Wild bee pollinators provide the majority of crop visitation across land-use gradients in New Jersey and Pennsylvania, USA. Journal of Applied Ecology 45:793-802.

Wood TJ, Holland JM, Goulson D (2015) Pollinator-friendly management does not increase the diversity of farmland bees and wasps. Biological Conservation 187:I20-I26. [online] URL: http://linkinghub.elsevier.com/retrieve/pii/S00063207150017 55

Xie Z, An J (20I4) The effects of landscape on bumblebees to ensure crop pollination in the highland agricultural ecosystems in China. Journal of Applied Entomology I38:555-565. 